\title{
症例報告：
}

\section{心尖部肥大型心筋症 $(\mathrm{APH})$ と診断された17年後に心室頻拍， 心不全をきたし，心尖部心室瘤が確認された 1 例}

\author{
大 森 芳*, 高橋 俊明*, 武田智*, 深堀耕 平* \\ 吉田正行*，伏見悦子*，関口展代*，渡辺 -* \\ 林雅 人*
}

症例は73歳男性。56歳時, 心電図にて左室高電位, 巨大陰性 T（GNT）を認めたため 心臓カテーテル検査を行い, スペード型左室変形から心尖部肥大型心筋症 (APH) と診 断されたが，6か月で治療を中断していた。2000年 3 月 31 日, 非持続性心室頻拍にて当科 に入院した。心電図では 17 年前よりも R 波が減高し, GNT が消失, 胸部誘導で $\mathrm{ST}$ 上昇, QRS 幅が延長していた。左室造影で心室中部の閉塞（収縮期圧較差 $56 \mathrm{mmHg}$ ）と心尖部 心室瘤を認めた。冠動脈に器質狭窄なし。心エコーで拡張早期に心尖部から左室流出路方 向に向かう奇異性血流を認めた。 $\beta$ ブロッカー, アミオダロンで心室頻拍は消失した が, 1 か月後心不全のため再入院した。心尖部心室瘤, 心不全などを生じる APH の特徴 として, 心電図での R 波・院性 T の減高, QRS 幅増大, ST 上昇, 心エコードップラー での左室拡張早期奇異性血流（diastolic paradoxic flow）などに留意すべきである。

\section{(1)心尖部肥大型心筋症 (2)心尖部心室瘤 (3)心室頻拍 (4)左室拡張早期奇異性血流}

本邦の Sakamoto ら ${ }^{1)}$, Yamaguchi ら ${ }^{2)}$ は, 心電図で巨大陰性 $\mathrm{T}$ 波を呈し心尖部に肥大が 限局する症例を apical hypertropyとして報告 した。一方 Maron ら゙が報告したapical hypertrophic cardiomyopathyはスペード型左室 変形や巨大陰性 $\mathrm{T}$ を示す例が少なかったこと から，本邦と欧米の心尖部肥大の概念の異同が 論争となった。本邦の apical hypertrophy は 非対称性中隔肥大を呈する古典的な肥大型心筋 症 (HCM) とは異なる病態で, Japanese Type の心尖部肥大型心筋症 $(\mathrm{APH})^{4)}$ と呼ばれるべ きことが明らかとなった。本症は左室造影でス ペード型左室変形を示し, 30歳以上の中高齢男 性に多く, 家族歴は稀で, 心機能障害の程度は

\footnotetext{
* T 013-8610 秋田県横手市駅前町 1 番30号

平鹿総合病院第二内科

（受付：2001年 8 月23日）
}

比較的軽く予後は良好であるなどの臨床的特徵 がある5)。

しかし，予後良好といわれた APHも長期に わたる経過観察中に心機能障害をきたしたり， 心尖部心室瘤を形成する重症例が散見されるよ うになった ${ }^{6 \sim 9)}$ 。今回われわれは APH と診断 された 17 年後に心尖部心室瘤を形成し，心室頻 拍，心不全をきたした 1 例を経験したので報告 する。

\section{症例}

症例 : 73歳, 男性。

家族歴：突然死の家族歴なし。

既往歴：1973年の検診で軽度高血圧を指摘さ れ一時的に降圧薬を服用したが，数か月で中 断。1976年の検診で心電図異常を指摘されたが 放置。1982年，再び心電図異常を指摘されたた 
め, 1983年（56歳時）当院を受診した。心電図 (図 1), 心エコー, 心蔵カテーテル検査（図

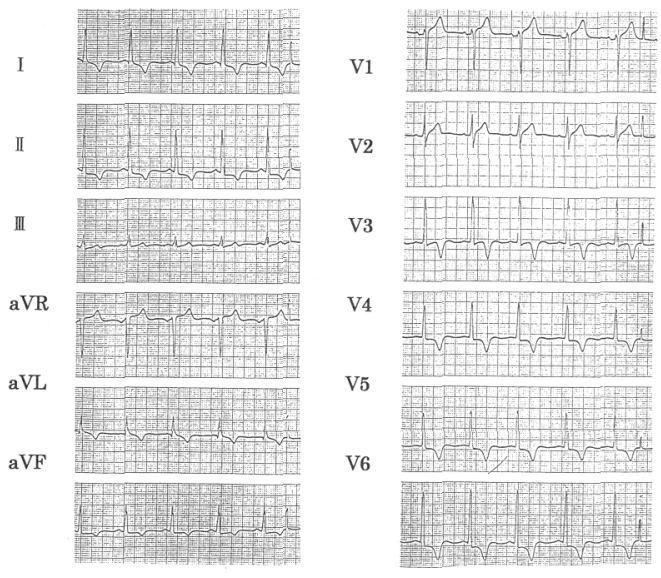

図 1．12誘導心電図 $(1983.2 .1)$

洞調律, $\mathrm{RV}_{5} 34 \mathrm{~mm}, \mathrm{SV}_{1}, 17 \mathrm{~mm}, \mathrm{QRS}$ 幅0.08 秒，最大㓌性 $\mathrm{T}$ 波高 $14 \mathrm{~mm}\left(\mathrm{~V}_{4}\right)$ 。

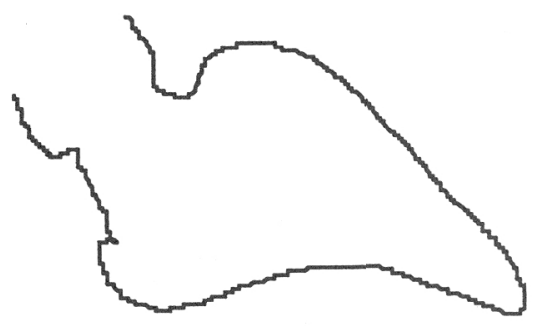

拡張期

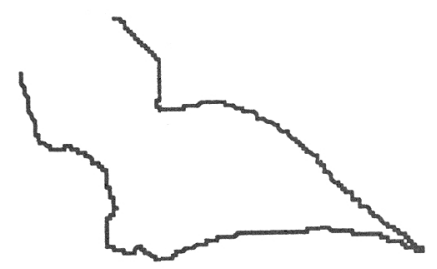

収縮期
2)にて $\mathrm{APH}$ と診断された。その後 6 か月間 通院したが，自己中断していた。その後は1991 年から毎年検診を受けていたが，一度も精查は していなかった。

現病歴：2000年 3 月29日から 1 日に 1 回程 度，数秒間の眼前暗黑感が出現し，3月31日午 後からは頻回に起こるようになったため，近医 を受診した。心電図で心室頻拍が認められたた め，当院に救急搬送された。

身体所見：身長 $154.4 \mathrm{~cm}$, 体重 $64.2 \mathrm{~kg}$, 意識 清明, 血压 $169 / 89 \mathrm{mmHg}$, 脈拍 113 /分, 不 整。結膜に貧血, 黄疸なし。胸部にラ音なし, 胸骨左縁第 3 肋間に収縮期雑音を認めた。腹部 に異常なく，下腿に軽度浮腫を認めた。

検查所見：血液生化学検查に異常なし。胸部 $\mathrm{X}$ 線では心胸郭比 $53 \% ，$ 肺野に異常なし。

心電図 (図 3 ) は心拍数 120 分の洞頻脈で I，aVL，V4-6で陰性 Tを認め，心室頻拍の
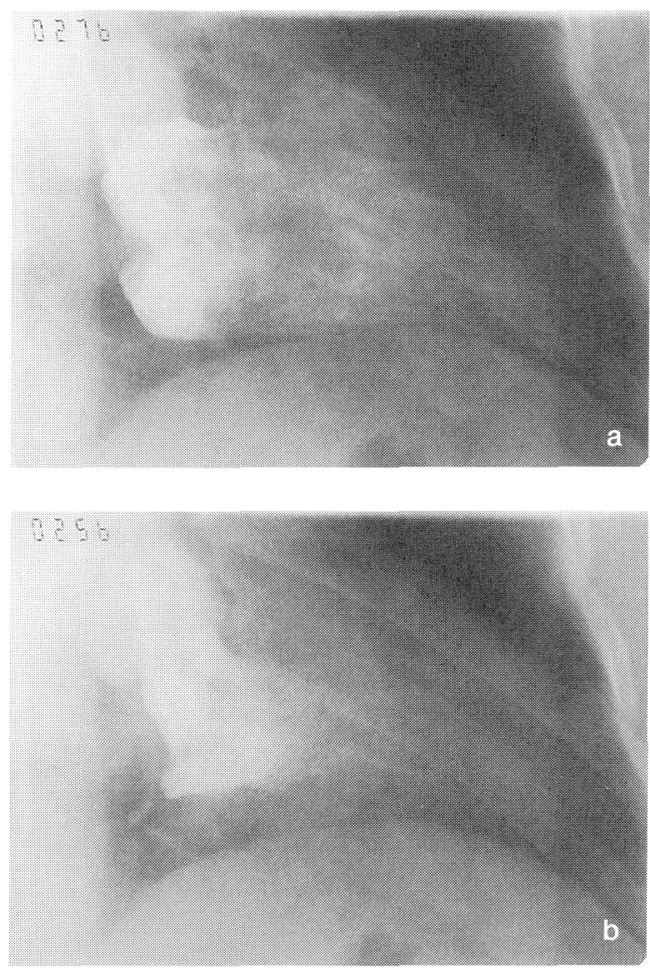

図 2. 左室造影（1983.2.1 a ：拡張期，b：収縮期） 心尖部の全周性肥厚のため左室内腔はスペード型を呈する。左室拡 張終期圧は $12 \mathrm{mmHg}$ だった。 
ショートランが繰り返し生じていた。心エコー では左室心尖部長軸像で心室中隔中部の肥厚, 収縮期の左室中部内腔の捩小化と心尖部心室瘤 を認めた。パルスドップラー法 (図 4) では収 縮期から拡張早期にかけて, 心尖部から心基部 に向かう二峰性の血流パターンが記録された。

第19病日に心臓カテーテル検查を行った。左 室造影（図 5 ）では収縮期に左室内腔が心基部 と心尖部に分断されたいわゆる砂時計状の形

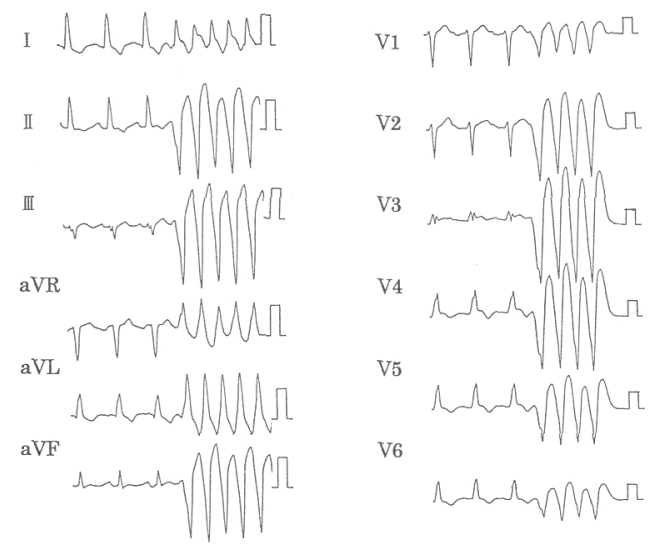

図 3.12誘導心電図 (2000.3.31)

洞調律, $\mathrm{RV}_{5} 16 \mathrm{~mm}, \mathrm{SV}_{1} 21 \mathrm{~mm}, \mathrm{QRS}$ 幅0.12 秒，最大陰性 $\mathrm{T}$ 波高 $3 \mathrm{~mm}$ (V 5)，III，V3-5 で軽度 ST上昇を認める。

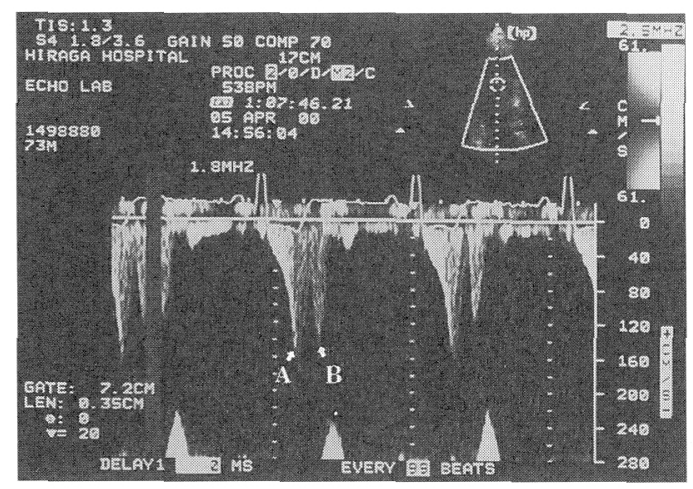

図 4。心エコーパルス・ドップラー

(2000.4.5)

収縮期(A)から拡㖘期(B)にかけて, 心尖部から 心基部への二峰性の血流パターンを認める。 flow Aのピークは約 $2.5 \mathrm{~m} /$ 秒で, 収縮後半に シグナルの減弱を認める。
態を呈していた。心尖部は収縮期に膨隆し, 心室瘤と考えられた。心尖部内压は183/18 $\mathrm{mmHg}$, 心基部は $127 / 17 \mathrm{mmHg}$ で, 収縮期 の圧較差は $56 \mathrm{mmHg}$ であった。冠動脈は左右 とも狭窄を認めなかった。心筋シンチグラ フィーでは ${ }^{99} \mathrm{Tc}$ 血流シンチ, ${ }^{123} \mathrm{I}$ BMIPP 脂肪 酸代謝シンチいずれでも左室心尖部の取り达み 低下を認めた。

以上の所見から本例を経過中に心室中部閉塞 と心室瘤を形成した $\mathrm{APH}$ と診断した。 $\beta$ 遮断 薬，アミオダロンの投与で心室頻拍は抑制され 退院したが，1 か月後急性左心不全のため再入 院した。利尿剂投与で速やかに改善した。

検診を含めた心電四所見の経年変化を表 1 に 示した。1991年には, RV $520 \mathrm{~mm}$, 最大陰性
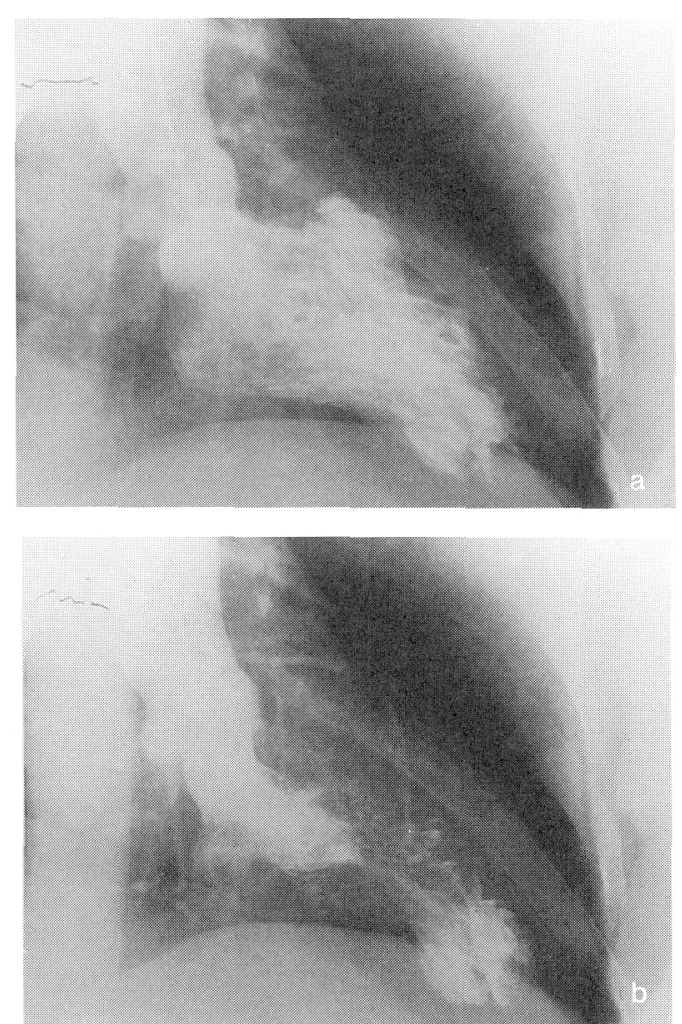

図 5. 左室造影

(2000.4.17 a : 拡張期，b：収縮期) 左室中部が肥大し, 収縮期には砂時計状を呈 する。心尖部は収縮期に䐍隆し，心室瘤を形 成している。 
表 1. 心電図所見の経年変化

\begin{tabular}{cccccl} 
& SV1 & RV5 & 最大陰性T & QRS偪 & ST上昇 \\
\hline 1983.2.8. & 17 & 34 & 14 & 0.08 & V3 \\
91.5 .20$. & 23 & 20 & 6 & 0.10 & V2,3 \\
93.6 .3$. & 21 & 19 & 7 & 0.10 & V2,3 \\
96.7 .22$. & 23 & 20 & 4 & 0.11 & II ,aVF, V3,4 \\
98.4 .30$. & 23 & 19 & 3 & 0.12 & II, III, aVF,V3-5 \\
2000.3.31. & 21 & 16 & 3 & 0.12 & III,V3-5 \\
\hline
\end{tabular}

単位 : SV1,RV5,最大陰性 T; mm QRS偪; 秒

$\mathrm{T}$ 波 高 $6 \mathrm{~mm}, \mathrm{QRS}$ 幅0.10秒, V 2,3 で $\mathrm{ST}$ 上昇が認められた。これら $\mathrm{R}$ 波・ $\mathrm{T}$ 波高, $\mathrm{QRS}$ 幅は1983年（図 1) と2000年（図 3 ）のほぼ中 間の值であった。

\section{考察}

APH あるいはHCM を長期に経過観察した 報告には次のようなものがある。

楠川ら ${ }^{8)}$ は APH 13例のうち 2 例が 8 10年 後に心尖部心室瘤を形成したと報告した。石綿 ら ${ }^{9)}$ は HCM 82例（閉塞型12例，非閉塞型30 例, APH 40例）を平均11.7年経過観察し, 心 不全, 拡張型心筋症（DCM）化する例が $4 \%$ みられ， $\mathrm{APH}$ の 2 例が心尖部壁運動異常をき たしたと述べている。また HCM 62 例を 8 年間 観察した Fighali ら ${ }^{10)}$ の報告では，このうちの 5 例が左室びまん性あるいは局所性壁運動異常 を呈したという。

従って, $\mathrm{APH}$ を含む HCM の $5 \sim 10 \%$ 程度 は10年前後で心機能障害や心尖部心室瘤を生 じ，決して予後良好とはいえないことがわか る。これらの報告を踏まえて松原ら ${ }^{11)}$ は本症の 自然歴を肥大の発生・進展期, 安定期, 変性期 の 3 期に分けている。

そこで $\mathrm{HCM}$ ，殊に $\mathrm{APH}$ が変性期に移行す る徴候を明らかにするために，変性の病理とそ れにいたる病態生理を理解する必要がある。

$\mathrm{HCM}$ 変性期の心筋の病理学的変化には急性 心筋梗塞を合併する場合もあるが10,12,13)，臨床 的には潜在性に心筋の線維化を生じる例が多 ( $^{7,9,14 \sim 16)}$ 。Maron $ら^{14)}$ は臨床的, 形態学的に 貫壁性心筋梗塞を伴っていると考えられた $\mathrm{HCM}$ の剖検例 7 例の検討で, 心筋内冠動脈壁
の肥厚と貫壁性の心筋線維化を認めたが，この うち急性心筋梗塞の臨床像を示したのは 1 例だ けだったと報告した。石綿ら ${ }^{9)} \mathrm{APH}$ を含む $\mathrm{HCM} 82$ 例中 8 例に新たな異常 $\mathrm{Q}$ 波の出現を認 めたが，いずれの症例も明らかな心筋梗塞の既 往はなく, 長期にわたって徐々に変化したこと を指摘し, 通常の動脈硬化による心筋梗塞とは 成因が異なると考えている。

杉原ら ${ }^{17)}$ は APH 28例に運動負荷心筋シンチ を行い，負荷直後像で19例（68\%）に心尖部の 灌流低下を認めた。逑延像ではこのうちの15例 は完全再分布したが，不完全再分布あるいは固 定灌流低下を呈した残りの 4 例は心尖部の壁運 動異常を伴っており, 完全再分布は収縮期の冠 予備能の低下を, 不完全再分布あるいは固定灌 流低下は線維化を意味すると推測している。 APH の心尖部心筋を病理学的に検討すると, 心尖部壁運動異常のない例では心筋細胞の錯綜 配列と散在性の線維化がみられ ${ }^{18)}$, 心室瘤を生 じた例では心筋線維のほとんどが線維組織に置

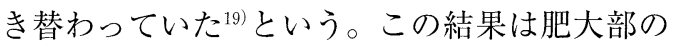
慢性的な虚血による変化を裏付けるものといえ る。

HCM の変性（心尖部心室瘤形成）を引き起 こす慢性虚血の原因として Fighali ら ${ }^{10)}$ は，肥 大した心尖部心筋による心室中部の閉塞に伴う 心尖部内圧の上昇と, 心尖部心筋のさらなる代 償性肥大によって增大した圧負荷をあげてい る。中村ら ${ }^{20)}$ は左室内狭窄により拡張早期に圧 較差が生じ, 心尖部の高圧が持続して心筋灌流 が障害されるためと推測した。また石綿ら゙は 心尖部の肥大した異常心筋の一部に脆弱な部分 があり，常に高圧にさらされるうちに心筋の退 
縮が加わって瘤が形成されると述べている。い ずれにせよ，収縮期，あるいは拡張期まで続く 左室内圧較差の存在が圧負荷, 虚血を介して瘤 形成に至ると考えられる。

以上のことから, 左室内圧較差による左室内 異常血流, その結果としての心尖部分離現象の 検出，および心電図変化などが変性期移行への 目安になると考えられる。

\section{1. 左室内異常血流}

左室内に圧較差を生じると，拡張期に心尖部 から心基部に向かう奇異性血流，あるいは収縮 期に心尖部から心基部へ向かう血流が突然途絶 するなどの左室内血流の異常 ${ }^{7,15,20 ~ 22)}$ が認めら れる。これは収縮期に心室中部が閉塞すると心 尖部の腔が高圧になり, 拡張早期に閉塞が解除 されるとともに血流が狭窄部位を通過するため

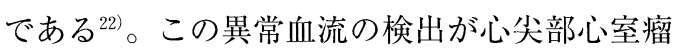
形成, 内圧上昇に伴う虚血や不整脈誘発の初期 の指標になるとされる7)。さらに拡張期奇異性 血流を伴う症例の30\%に血栓症，50\%に心室頻 拍が合併したという報告もある22)。

\section{2. 心尖部分離現象}

心エコー, 左室造影などにおける心尖部分離 現象 ${ }^{20)}$ の検出も重要である。心尖部分離腔の大 きさは様々で23), 小さく島状に心尖部から遠く 分離されたり，大きく心室瘤様に左室腔を二分 して全体として砂時計状を呈する例もある20)。

\section{3. 心電図変化}

HCM，APH の心電図を長期に観察すると， 異常 $\mathrm{Q}$ 波, 10,12,21), $\mathrm{R}$ 波・陰性 $\mathrm{T}$ 波の減高7,9,10,12, ${ }^{15,21,24)}$, ST 上昇 ${ }^{9,11,21)}, \mathrm{QRS}$ 幅延長 (心室内伝 導障害) ${ }^{8,15,16,21)}$ などが認められる。石綿ら ${ }^{9}$ は $\mathrm{HCM}$ の約 $10 \%$ Q 波出現, R 波減高とそれに 伴う壁運動異常の発現をみたという。中村ら ${ }^{15)}$ は $\mathrm{APH}$ を 8 年間追跡し, $\mathrm{R}$ 波の増減と陰性 $\mathrm{T}$ の増減は平行し, $\mathrm{R}$ 波の減高群では高頻度に心 尖部の血流シンチの欠損, 心尖部壁運動異常を 認めたと述べている。Koga ら ${ }^{24)}$ は APH の巨 大陰性 $\mathrm{T}$ は $5 \sim 9$ 年のうちに $31 \%, 10$ 年で $71 \%$ の例で消失したことを観察した。さらに諏訪 $ら^{16)}$ は HCM に心筋生検を行い, 心電図におけ る左室電位の減衰, 心室内伝導障害は左室の有
意の線維化の反映であると結論している。また 高血圧性心肥大では，QRS 幅延長が心機能不 全を示唆することが示されている ${ }^{25)}$

改めて本例の経過を振返ってみると，1983年 の左室造影ではカテーテルが浅く心尖部まで充 分造影されていないため, 心尖部分離腔の有無 は判然としない。また心エコードップラー所見 の記載はなく, 異常血流についても不明であ る。しかし1991年の心電図にはすでに R 波・ 陰性 T の減高とQRS 幅の延長傾向, おょび $\mathrm{ST}$ 上昇が見られ，その後この傾向はさらに顕 著になってきている。従って，この17年間に左 室の変性が進行し, 精查が行なわれていればか なり初期の時点で異常血流や心尖部分離腔が捉 えられた可能性が高い。

また， 1 か月後の心不全による再入院時に左 室収縮能は保たれていた (EF 61\%)。拡張不 全が心不全の原因と考えられた。

$\mathrm{APH}$ の一部に予後不良例のあることが明ら かとなったが, 本症に対して従来から閉塞性肥 大型心筋症に有効とされている $\beta$ 遮断薬, $\mathrm{Ca}$ 拮抗薬, Ia 群抗不整脈薬, DDD ペーシングな ど23)の治療が有効かどうか今後検討される必要 がある。

\section{文献}

1) Sakamoto $T$, Tei $T$, Murayama M, et al. Giant $T$ wave inversion as a manifestation of asymmetrical apical hypertrophy (AAH) of the left ventricle. Jap Heart J $1976 ; 17$ : 611.

2) Yamaguchi H, Ishimura T, Nishiyama $\mathrm{S}$, et al. Hypertrophic nonobstructive cardiomyopathy with giant negative $\mathrm{T}$ waves (apical hypertrophy): Ventriculographic and echocardiographic features in 30 patients. Am J Cardiol 1979; 44 : 401.

3 ) 古賀義則. 心臟病プラクテイス 11 心筋疾患を知 る, 第 1 版. 東京: 文光堂, pp. 2-9.

4) Maron BJ, Bonow RO, Seshagiri TNR, et al. Hypertrophic cardiomyopathy with ventricular septal hypertrophy localized to the apical region of the left ventricle (Apical hypertrophic cardiomyopathy). Am J Cardiol 1982 ; 49 : 1838.

5 ) Maron BJ, Louie EK. Apical hypertrophic cardiomyopathy : A review from the U.S.A. J Cardiogr $1986 ; 16: 513$. 
6 ）田川博之, 伏見悦子, 高橋俊明, 他. 心尖部左心 室瘤を合併した心室中部閉塞性肥大型心筋症によ り脳塞栓をきたしたと考えられた 1 例。心臓 $1998 ; 30: 741$.

7 ) 井上 卓, 砂川長彦, 當真 隆, 他. 経過中に心 室中部閉塞と心室瘤を形成した心尖部肥大型心筋 症の 1 例. J Cardiol $1999 ; 33: 217$.

8 ）楠川順也, 諏訪通博, 中山 康, 他. 心尖部肥大 型心筋症の経年変化: 経過中, 心尖部領域の壁運 動異常を呈した 2 例. J Cardiol 1988；18：259.

9 ）石綿清雄, 西山信一郎, 中西成元, 他. 肥大型心 筋症82例の予後の検討：10年間の自然経過と臨床 所見に関して.J Cardiol $1991 ； 21: 61$.

10) Fighali S, Krajcer Z, Edelman S, et al. Progression of hypertrophic cardiomyopathy into a hypokinetic left ventricule: Higher incidence in patients with midventricular obstruction. J Am Coll Cardiol $1987 ; 9: 288$.

11）松原欣也. 肥大型心筋症, 第 1 版. 京都：金芳堂, 2000, pp. 128-139.

12) Webb JG, Sasson Z, Rakowski H, et al. Apical hypertrophic cardiomyopathy:Clinical follow-up and diagnostic correlates. J Am Coll Cardiol $1990 ; 15: 83$.

13）伊藤正洋, 広野 暁, 佐伯牧彦, 他. 急性心筋梗 塞をきたした器質的冠狭窄のない閉塞性肥大型心 筋症の 2 例. 心臟 $1999 ; 31: 601$.

14) Maron BJ, Epstein SE, Roberts WC. Hypertrophic cardiomyopathy and transmural myocardial infarction without signficant in atherosclerosis of the extramural coronary arteries. Am J Cardiol $1979 ; 43: 1086$.

15）中村隆志, 古川啓三, 松原欣也, 他. 心尖部肥大 型心筋症に扔ける心電図経年变化の意義. J Cardiol $1990 ; 20: 635$.

16）諏訪道博, 米田 豊, 中山 康, 他. 肥大型心筋
症の心電図上の経年変化と予後との関連につい て. 厚生省特定疾患 62 年度研報 - 特発性心筋症調 查研究, 1987, pp. 197-201.

17）杉原洋樹, 谷口 洋, 大槻克一, 他. 心尖部肥大 型心筋症の心筋灌流異常. 運動負荷 ${ }^{201} \mathrm{~T} 1$ 心筋 SPECTによる検討. 呼と循 $1993 ; 41: 1089$.

18) Sumino $S$, Sugimoto $T$, Koide $T$, et al. Necropsy finding in patient with apical hypertrophic cardiomyopathy. Jpn Heart J 1985 ; 26 : 297.

19) Barbaresi F, Longhini C, Brunazzi C, et al. Idiopathic apical left ventricuar aneurysm in hypertrophic cardiomyopathy. Report of 3 cases, and review of literature. Jpn Heart J $1985 ; 26$ : 481.

20）中村隆志，松原欣也，古川啓三，他. 肥大型心筋 症における心尖部分離現象：その臨床像と病態. J Cardiol $1991 ; 21: 361$.

21）関口洋平, 池田 淳, 杉 正文, 他. 非閉塞性肥 大型心筋症から心室中部閉塞性肥大型心筋症への 進展を確認した 1 症例。心臟 $1993 ； 25 ： 1058$.

22) Nakamura T, Matubara K, Furukawa K, et al. Diastolic paradoxic jet flow in patients with hypertrophic cardiomyopathy: Evidence of concealed apical asynergy with cavity obliteration. Am Coll Cardiol 1990; $19: 516$.

23) Wigle ED, Rakowiki H, Kimball BP, et al. Hypertrophic cardiomyopathy. Clinical spectrum and treatment. Circulation $1995 ; 92: 1680$.

24) Koga Y, Katoh A, Matsuyama K, et al. Disappearance of giant negative $T$ waves in patients with the Japanease form of apical hypertrophy. J Am Coll Cardiol $1995 ; 26: 1672$.

25）高橋俊明, 伏見悦子, 関口展代, 他. 高血圧性心 肥大による心不全. 心電図所見の特徴と心エコー による左室心筋重量係数. 呼と循 $2000 ; 48 ： 181$. 


\title{
A case of Left Ventricular Apical Aneurysm with Ventricular Tachycardia and Congestive Heart Failure Detected 17 Years after the Diagnosis of Apical Hypertrophic Cardiomyopathy
}

\author{
Kaori OHMORI*, Toshiaki TAKAHASHI* , Satoru TAKEDA*, \\ Kohei FUKAHORI*, Masayuki YOSHIDA*, Etsuko FUSHIMI*, \\ Nobuyo SEKIGUCHI* Hajime WATANABE* ${ }^{*}$ and Masato HAYASHI ${ }^{*}$
}

A 73-year-old man was admitted to the hospital on March 31, 2000 because of nonsustained ventricular tachycardia (VT). In 1983, he was diagnosed as having apical hypertrophic cardiomyopathy (APH). Electrocardiograms showed high amplitude of $R$ waves and giant negative T waves (GNT), and left ventriculography (LVG) revealed spade like configuration. He stopped medication without leave six months after the diagnosis. The latest ECG showed a decrease in amplitude of $R$ waves, no signs of GNT, ST elevation in precordial leads, and an increase in QRS duration. LVG demonstrated midventricular obstruction, apical aneurysm, and the intraventricular pressure gradient in systolic phase was $56 \mathrm{~mm} \mathrm{Hg}$. No stenotic lesion was observed in coronary arteriography. Early diastolic paradoxic flow from the apical chamber toward the outflow of the left ventricle was detected by pulsed Doppler echocardiography. VT was successfully treated with beta-blocker and amiodarone, but he needed hospital treatment again one month later because of congestive heart failure. During the follow-up of APH, the decrease in amplitude of $\mathrm{R}$ waves and disappeasance of GNT, ST elevation, and the increase in QRS duration in electrocardiograms, and the detection of early diastolic paradoxic flow by echocardiography could be the predictors of developing apical aneurysm and/or left ventricular dysfunction.

\footnotetext{
${ }^{*}$ The Second Dept. of Internal Medicine, Hiraka General Hospital, Akita, Japan
} 